\title{
The second internal transcribed spacer of nuclear ribosomal DNA as a tool for Latin American anopheline taxonomy - A critical review
}

\author{
Mauro Toledo Marrelli, Maria Anice Mureb Sallum, Osvaldo Marinotti*/+ \\ Departamento de Epidemiologia, Faculdade de Saúde Pública, Universidade de São Paulo, São Paulo, SP, Brasil \\ *Department of Molecular Biology and Biochemistry, University of California Irvine McGaugh Hall, Room 2315, 92697-3900, \\ Irvine, CA, US
}

Among the molecular markers commonly used for mosquito taxonomy, the internal transcribed spacer 2 (ITS2) of the ribosomal DNA is useful for distinguishing among closely-related species. Here we review 178 GenBank accession numbers matching ITS2 sequences of Latin American anophelines. Among those, we found 105 unique sequences corresponding to 35 species. Overall the ITS2 sequences distinguish anopheline species, however, information on intraspecific and geographic variations is scarce. Intraspecific variations ranged from $0.2 \%$ to $19 \%$ and our analysis indicates that misidentification and/or sequencing errors could be responsible for some of the high values of divergence. Research in Latin American malaria vector taxonomy profited from molecular data provided by single or few field capture mosquitoes. However we propose that caution should be taken and minimum requirements considered in the design of additional studies. Future studies in this field should consider that: (1) voucher specimens, assigned to the DNA sequences, need to be deposited in collections, (2) intraspecific variations should be thoroughly evaluated, (3) ITS2 and other molecular markers, considered as a group, will provide more reliable information, (4) biological data about vector populations are missing and should be prioritized, (5) the molecular markers are most powerful when coupled with traditional taxonomic tools.

Key words: Anopheles - Neotropical - anophelines - malaria vectors - internal transcibed spacer 2 - ITS2 -

taxonomy - systematics

\section{ANOPHELES SIBLING SPECIES}

Many anopheline mosquitoes belong to species complexes that are difficult to differentiate using morphological criteria alone. These complexes may include both malaria vectors and nonvector species, which either may occur sympatrically, or have distinct geographical distributions (Collins \& Paskewitz 1996, Krzywinski \& Besansky 2003, Black \& Munstermann 2005). The Anopheles gambiae complex, as an example of an extensively studied taxonomic group, is composed of seven species, of which five are human malaria vectors. $A$. gambiae s.s. and A arabiensis are both major malaria vectors in Africa, however the former feeds mostly on humans while the latter feeds on both humans and cattle. Differently, A. quadriannulatus species A and B, members of the same complex, are mainly cattle feeders and do not transmit human malaria (Coetzee 2006). In Asia a similar scenario occurs in which A. mininus s.s. and $A$. varuna, both members of the $A$. minimus complex, have distinct feeding behaviors. A. minimus s.s. feeds both on humans and animals, and is a major malaria vector, while A. varuna is essentially zoophilic

Financial support: Fapesp (grants 05/50225-2 and 05/53973-0)

${ }^{+}$Corresponding author: omarinot@uci.edu

Received 29 May 2006

Accepted 1 November 2006 and does not play a role in Plasmodium vivax and $P$. falciparum transmission (Kittayapong 2006). Therefore, the proper identification of malaria vectors and their sibling species, together with the mapping of their geographical distribution, is of fundamental importance for malaria control programs that depend on this information to set up their actions and to establish protocols that will result in useful epidemiological data. Actions focused on areas where malaria vector species occur, in contrast with a widespread intervention, are beneficial since the burden of malaria is primarily situated in developing countries, which have limited economic resources to invest in public health programs (Van Bortel et al. 2001, McMichael et al. 2005).

Evidences for anopheline sibling species were first discovered during the 1920s and 1930s when mosquitoes of the A. maculipennis complex were shown to belong to distinct species by comparative studies of their eggshell coloring patterns, feeding behaviors and mating incompatibility (Black \& Munstermann 2005). Subsequently, different chromosomal forms were observed in specimens of $A$. maculipennis and these forms assigned to distinct species within the complex. While the cytogenetic approach has proven to be powerful for mosquito taxonomy [i.e. A. maculipennis and A. gambiae complexes (Frizzi 1947, 1953, Coluzzi 1966, Coetzee et al. 2000)], its application is time consuming and requires specialized skills.

Since then, researchers from around the world have pursued ways to recognize species within the various 
complexes of anophelines. As a result, ecological, behavioral, biochemical, and molecular studies have provided substantial data resulting in the improvement of mosquito taxonomy, and thus, A. albitarsis ( $\mathrm{Li} \&$ Wilkerson 2005), A. crucians (Wilkerson et al. 2004), A. culicifacies (Subbarao \& Sharma 1997), A. dirus (Huong et al. 2001), A. farauti (Beebe et al. 2000), A. gambiae (Powell et al. 1999), A. maculipennis (Romi et al. 2000), A. minimus (Jaichapor et al. 2005), and $A$. quadrimaculatus (Levine et al. 2004), are now recognized as species complexes. In addition, several other anopheline mosquito taxonomic groups are suspected to be complexes of cryptic species (Lounibos et al. 1998, Tadei \& Dutary-Thatcher 2000).

\section{THE INTERNAL TRANSCRIBED SPACER 2 (ITS2)} AS A MOLECULAR MARKER

Among the molecular markers used for mosquito taxonomy, the ITS2 of the ribosomal DNA genes is useful for distinguishing among specimens belonging to closely-related species. For example, the $A$. maculipennis complex (Porter \& Collins 1991), A. quadrimaculatus complex (Cornel et al. 1996) and $A$. culicifacies complex (Goswami et al. 2005) have been analyzed using this marker. In other complexes, composed of recently-diverged members, such as the $A$. gambiae, the ITS2 interspecies differences are minor, from 0.4 to $1.6 \%$ (Paskewitz et al. 1993), not allowing the use of this marker alone for taxonomic purposes. The sequences of the ITS2 of several Neotropical anophelines have been determined during the last decade and deposited in the GenBank public database. While these sequences have been analyzed and compared within each taxonomic group as contributions of individual researchers and laboratories, little or no efforts have been made to look at the more global pattern that this comprehensive data collection is generating. Therefore the organization and comparison of all the ITS2 sequences of Latin American anopheline mosquitoes, and an analysis of their relationships is the purpose of this review.

\section{LATIN AMERICAN ANOPHELINES}

Of the more than 500 species of Anopheles in the world approximately 100 occur in the Neotropical Region (Papavero \& Guimarães 2000). Of those found in Latin America, 29 have been indicated as confirmed or potential human malaria vectors (Table I). The principal vectors in Mexico and Central America are $A$. pseudopunctipennis and A. albimanus (Rodriguez 2006). In the Amazon area, where $95 \%$ of all Latin America malaria cases are reported, the major vector is A. darlingi (Deane 1986, Tadei \& Dutary-Thatcher 2000), an endophilic and antropophilic species highly susceptible to infection with Plasmodium parasites (Klein et al. 1991a,b). However, as mentioned above, these are not the only malaria vectors and research based on radioimmunoassay (RIA) and enzyme-linked immunosorbent assay (ELISA) for the detection of Plasmodium antigens in mosquitoes extracts, and mosquito dissection for the direct observation of parasites (oocysts and/or sporozoites), has identified other anopheline species playing potentially important roles in malaria transmission in specific locations in Latin America (de Arruda et al. 1986, Klein et al. 1991a,b, Zimmermann 1992, Branquinho et al. 1993,1996, Calderon et al. 1995, Marrelli et al. 1998, Tadei \& Dutary-Thatcher 2000). For example, Conn et al. (2002) conducted entomological surveys in malaria afflicted areas of Macapá (state of Amapá, Brazil) and found that $A$. marajoara was the most abundant anopheline, replacing $A$. darlingi as the primary vector. Most likely the observed change in mosquito population was a result of human activity (deforestation and newly created ground pools for agricultural use) that provided adequate breeding sites for $A$. marajoara. These data emphasize the challenges that malaria control agencies face in identifying specific target vectors in a dynamic scenario driven by constant human intervention in the environment. The possibility that the mosquitoes inhabiting these areas are distinct members of complexes of anopheline species, with varying degrees of vectorial capacity, further complicates the overall picture and makes it more difficult to define effective vector control interventions. A fundamental step towards the recognition of the target species is the accurate identification of field captured specimens. For most of the anopheline mosquitoes from Latin America, taxonomy based only on morphological characters has not presented much problem, however, molecular data have indicated that for some taxonomic groups the apparent simplicity of species identification may be deceptive.

\section{ITS2 OF LATIN AMERICAN ANOPHELINES}

The Neotropical anopheline species are classified into five subgenera: Nyssorhynchus, Kerteszia, Anopheles, Stethomyia, and Lophopodomyia (Faran \& Linthicum 1981, Sallum et al. 1999, Wilkerson \& Sallum 1999), but malaria vectors are only found within the first three subgenera. This fact dictated the interest of researchers and most of the Latin American anopheline biology information generated so far is concentrated on the Nyssorhynchus, Kerteszia, and Anopheles subgenera. Accordingly, our search of the GenBank data base for Latin American anopheline ITS2 sequences resulted in more than 150 entries that include data for most species registered as vectors of human malaria (Table I) (Tadei \& Dutary-Tatcher 2000, Deane 1986, Consoli \& Lourenço-de-Oliveira 1994, Marrelli et al. 2005). $A$. calderoni, A. punctimacula, A. neomaculipalpus, A. vestitipennis, and $A$. neivai have been indicated as human malaria vectors but have no ITS2 sequences available in the database. The acquisition of ITS2 sequences for these species should therefore be considered as the objective of near future studies. No ITS2 sequence data was found for mosquito species of the Stethomyia and Lophopodomyia subgenera.

One hundred seventy-eight ITS2 sequences were downloaded from the GenBank (data available on January 2006), corresponding to 35 different anopheline species. For the majority of species, more than one sequence is available. In these cases, the sequences were derived 
TABLE I

Latin American malaria vectors ${ }^{a}$

\begin{tabular}{|c|c|c|c|c|}
\hline Genus & Subgenus & Species & $\begin{array}{l}\text { ITS2 } \\
\text { sequence }\end{array}$ & Reference \\
\hline Anopheles & Anopheles & calderoni & No & Wilkerson (1991) \\
\hline Anopheles & Anopheles & mattogrossensis & Yes & Tadei \& Dutary-Thatcher (2000) \\
\hline Anopheles & Anopheles & mediopunctatus & Yes & Tadei \& Dutary-Thatcher (2000) \\
\hline Anopheles & Anopheles & near fluminensis & Yes & Hayes et al. (1987) \\
\hline Anopheles & Anopheles & neomaculipalpus & No & Moreno et al. (2005) \\
\hline Anopheles & Anopheles & peryassui & Yes & Tadei \& Dutary-Thatcher (2000) \\
\hline Anopheles & Anopheles & pseudopunctipennis & Yes & Rodriguez et al. (2000) \\
\hline Anopheles & Anopheles & punctimacula & No & Rubio-Palis \& Zimmernan (1997) \\
\hline Anopheles & Anopheles & vestitipennis & No & Grieco et al. (2005) \\
\hline Anopheles & Anopheles & quadrimaculatus & Yes & Robert et al. (2005) \\
\hline Anopheles & Kerteszia & bellator & Yes & Forattini et al. (1999) \\
\hline Anopheles & Kerteszia & cruzii & Yes & Carvalho-Pinto \& Lourenco de Oliveira (2004) \\
\hline Anopheles & Kerteszia & homunculus & Yes & Rubio-Palis \& Zimmernan (1997) \\
\hline Anopheles & Kerteszia & neivai & No & Carvajal et al. (1989) \\
\hline Anopheles & Nyssorhynchus & albimanus & Yes & Rodriguez et al. (2000) \\
\hline Anopheles & Nyssorhynchus & albitarsis & Yes & Tadei \& Dutary-Thatcher (2000) \\
\hline Anopheles & Nyssorhynchus & aquasalis & Yes & Zimmermann (1992) \\
\hline Anopheles & Nyssorhynchus & benarrochi & Yes & Flores-Mendonza et al. (2004) \\
\hline Anopheles & Nyssorhynchus & braziliensis & Yes & Tadei \& Dutary-Thatcher (2000) \\
\hline Anopheles & Nyssorhynchus & darlingi & Yes & Tadei \& Dutary-Thatcher (2000) \\
\hline Anopheles & Nyssorhynchus & deanorum & Yes & Rubio-Palis \& Zimmernan (1997) \\
\hline Anopheles & Nyssorhynchus & galvaoi & Yes & Tadei et al. (1998) \\
\hline Anopheles & Nyssorhynchus & marajoara & Yes & Moreno et al. (2005) \\
\hline Anopheles & Nyssorhynchus & nuneztovari & Yes & Tadei \& Dutary-Thatcher (2000) \\
\hline Anopheles & Nyssorhynchus & oswaldoi & Yes & Rosa-Freitas et al. (1998) \\
\hline Anopheles & Nyssorhynchus & rangeli & Yes & Povoa et al. (2001) \\
\hline Anopheles & Nyssorhynchus & strodei & Yes & de Oliveira-Ferreira et al. (1990) \\
\hline Anopheles & Nyssorhynchus & triannulatus & Yes & Tadei \& Dutary-Thatcher (2000) \\
\hline Anopheles & Nyssorhynchus & trinkae & Yes & Hayes et al. (1987) \\
\hline
\end{tabular}

$a$ : the species included in this table are those in which Plasmodium parasites have been detected by direct microscopic observation, immunological and molecular approaches. This comprehensive compilation allows the possibility of including false-positive data for mosquitoes that have just or recently fed on human blood infected with malaria. Also some mosquitoes may develop oocysts that do not complete their development into salivary gland sporozoites. As a result, one should be cautious about assuming that all these species are human malaria vectors. Supplemental biological and epidemiological data are a requirement to conclude that a species in fact transmits malaria to humans.

mostly from specimens collected in distinct localities and by different laboratories. Some species had several identical sequences deposited in the GenBank, corresponding to data obtained from different specimens. Therefore, sequences were first grouped, aligned and compared within each species. When individuals of a single species had identical sequences, we opted to consider only the first identical entry (Table II) in order to perform further analyses. For instance, among the 51 A. nuneztovari ITS2 entries, five different sequences were found ( $3 \%$ of intraspecific nucleotide divergence) with the sequence abbreviated as NUN5 representing $90 \%$ of the total (46 of 51 entries) (Tables II, III). Despite the dogma that concerted evolution makes the individual representative of the entire species (Liao 1999), extensive intraspecific variation has been reported for anophelines. Among the species included in this study (according to data from GenBank), ITS2 intraspecific variations ranged from 0.2 to $19.0 \%$. While ITS2 divergence does occur, we argue that where extensive ITS2 intraspecific variation is found, it should be taken as a signal that further investigation is necessary. As discussed below, misidentification and mislabeling of specimens and/or sequencing errors may account for some of the reported variability. Conversely, intraspecific heterogeneity of ITS sequences has been reported in other mosquito species, blackflies, and several other organisms (Tang et al. 1996). It is possible that in some cases low level of interbreeding occurs between different, closely related, sibling species concealling the effets of concerted evolution. Supporting this hypothesis, limited genetic introgression has been observed among members of the An. gambiae complex (Besansky et al. 1994, Kamau et al. 1998)

After all the sequences were organized and all identical sequences removed from the pool, the remaining 105 unique entries were used to construct a similarity tree (Fig. 1, nucleotide distances estimated 
TABLE II

Nucleotide sequences of the second internal transcribed spacer (ITS2) of nuclear ribosomal DNA of Latin American Anopheles mosquitoes available in the GenBank (April 2006) and included in this study

\begin{tabular}{lllll}
\hline Species & Subgenus & Seq. abbr. & Accession number & References \\
\hline A. bradleyi & Anopheles & BRAD1 & AY386967.1 & Wilkerson et al. (2004) \\
A. crucians & Anopheles & CRUC1 & AY386966.1 & Wilkerson et al. (2004)
\end{tabular}

A. eiseni
A. fluminensis
A. freeborni
A. hermsi
A. mattogrossensis
A. mediopunctatus
A. occidentalis
A. peryassui
A. pseudopunctipennis
A. quadrimaculatus

Anopheles

Anopheles

A. bellator
A. cruzii

A. homunculus

A. laneanus

A. albimanus

A. albitarsis

A. aquasalis

argyritarsis
Anopheles

Anopheles

Anopheles

Anopheles

Anopheles

Anopheles

Anopheles

Anopheles

CRUC2

CRUC3

CRUC4

CRUC5

EIS1

FLU1

FREE1

HERM1

MATTO1

MED1

OCCI1

PER1

PSEU1

QUADRI1

QUADRI2

QUADRI3

QUADRI4

Kerteszia

BELLA1

Kerteszia

CRUZ1

CRUZ2

CRUZ3

CRUZ4

Kerteszia

Kerteszia

HOMUN1

LANEA1

Nyssorhynchus

ALBIM1

ALBIM2

Nyssorhynchus

ALBIT1

ALBIT2

ALBIT3

Nyssorhynchus

AQUA1

AQUA2

AQUA3

AQUA4

AQUA5

AQUA6

AQUA7

AQUA8

AQUA9

AQUA10

AQUA11

AQUA12

AQUA13

AQUA14

AQUA15

Nyssorhynchus
ARGY1

ARGY2

ARGY3

ARGY4
AY386965.1

AY386964.1

AY386963.1

AY245553.1

AF462380.1

DQ328638

M64484.1

M64483.1

AF461754.1

AF462379.1

M64482.1

AF461755.1

U49735.1

U32506.1

U32505.1

U32504.1

U32503.1

DQ364652

AF027165.1

AF035227.1

DQ364653

DQ364654

DQ364656

DQ364655

U92323.1

L78065.1

AF462387.1

AF462386.1

AF462385.1

DQ020135.1

DQ020136.1

DQ020134.1

DQ020133.1

DQ020132.1

DQ020131.1

DQ020130.1

DQ020129.1

DQ020128.1

DQ020127.1,

DQ020125.1

DQ020126.1

DQ020124.1

DQ020123.1

AF462376.1

DQ020137.1

AY849554.1

AY849553.1

U92356.1

U92347.1
Marrelli et al. (2005)

Brelsfo et al. (unpublished) ${ }^{a}$

Porter \& Collins (1991)

Porter \& Collins (1991)

Marrelli et al. (2005)

Marrelli et al. (2005)

Porter \& Collins (1991)

Marrelli et al. (2005)

Miller et al. (1997)

Cornel et al. (1996)

Malafonte at al. (unpublished)

Malafronte et al. (unpublished)

Malafonte at al (unpublished)

Malafonte at al (unpublished)

Danoff-Burg \& Conn (unpublished), Collins (unpublished)

Marrelli et al. (2005)

Fairley et al (2005)

Marrelli et al. (2005)
Wilkerson et al. (2005),

Danoff-Burg \& Conn (unpublished) 


\begin{tabular}{|c|c|c|c|c|}
\hline Species & Subgenus & Seq. abbr. & Accession number & References \\
\hline A. benarrochi & Nyssorhynchus & $\begin{array}{l}\text { BEN3 } \\
\text { BEN4 }\end{array}$ & $\begin{array}{l}\text { U92325.1 } \\
\text { AY684976.1, } \\
\text { AY684977.1, } \\
\text { AY684978.1, } \\
\text { AY684979.1, } \\
\text { AY684980.1, } \\
\text { AY684981.1, } \\
\text { AY684982.1, } \\
\text { AY684983.1, } \\
\text { AY684984.1 } \\
\text { AF462384 } \\
\text { AF463483 }\end{array}$ & $\begin{array}{l}\text { Marrelli et al. (2005), } \\
\text { Ruiz et al. (2005), } \\
\text { Danoff-Burg \& Conn (unpublished) }\end{array}$ \\
\hline A. braziliensis & Nyssorhynchus & BRAZ1 & $\begin{array}{l}\text { AF461753.1, } \\
\text { U92336.1 }\end{array}$ & $\begin{array}{l}\text { Marrelli et al. (2005), } \\
\text { Danoff-Burg \& Conn (unpublished) }\end{array}$ \\
\hline A. darlingi & Nyssorhynchus & $\begin{array}{l}\text { DAR1 } \\
\text { DAR2 } \\
\text { DAR3 } \\
\text { DAR4 }\end{array}$ & $\begin{array}{l}\text { AF032133.1 } \\
\text { U36780.1, } \\
\text { U92337.1 } \\
\text { AF462388.1 } \\
\text { AF462389.1 }\end{array}$ & $\begin{array}{l}\text { Malafronte et al. (1999), } \\
\text { Marrelli et al. (2005), } \\
\text { Danoff-Burg \& Conn (unpublished) }\end{array}$ \\
\hline A. deaneorum & Nyssorhynchus & $\begin{array}{l}\text { DEAN1 } \\
\text { DEAN2 } \\
\text { DEAN3 } \\
\text { DEAN4 }\end{array}$ & $\begin{array}{l}\text { U92335.1 } \\
\text { AF461751.1 } \\
\text { AF461752.1 } \\
\text { AY828343.1 }\end{array}$ & $\begin{array}{l}\text { Li \& Wilkerson (2005), } \\
\text { Marrelli et al. (2005), } \\
\text { Danoff-Burg \& Conn (unpublished) }\end{array}$ \\
\hline A. dunhami & Nyssorhynchus & $\begin{array}{l}\text { DUN1 } \\
\text { DUN2 }\end{array}$ & $\begin{array}{l}\text { U92326.1 } \\
\text { AF462378.1 }\end{array}$ & $\begin{array}{l}\text { Danoff-Burg \& Conn } \\
\text { (unpublished), Marrelli et al. (2005) }\end{array}$ \\
\hline A. evansae & Nyssorhynchus & $\begin{array}{l}\text { EVAN1 } \\
\text { EVAN2 } \\
\text { EVAN3 }\end{array}$ & $\begin{array}{l}\text { U92327.1 } \\
\text { Y09240.1 } \\
\text { AF461750.1 }\end{array}$ & $\begin{array}{l}\text { Marrelli et al. (2005), } \\
\text { Fritz(1998), } \\
\text { Danoff-Burg \& Conn (unpublished) }\end{array}$ \\
\hline A. galvaoi & Nyssorhynchus & GALV1 & U92328.1 & Danoff-Burg \& Conn (unpublished) \\
\hline A. konderi & Nyssorhynchus & $\begin{array}{l}\text { KON1 } \\
\text { KON2 } \\
\text { KON3 }\end{array}$ & $\begin{array}{l}\text { U92342.1 } \\
\text { U92348.1 } \\
\text { U92349.1 }\end{array}$ & Danoff-Burg \& Conn (unpublished) \\
\hline A. marajoara & Nyssorhynchus & $\begin{array}{l}\text { MARA2 } \\
\text { MARA3 } \\
\text { MARA4 } \\
\text { MARA5 } \\
\text { MARA6 } \\
\text { MARA7 }\end{array}$ & $\begin{array}{l}\text { AY028127.1, } \\
\text { U92334.1, } \\
\text { AY828353.1, } \\
\text { AY828345.1, } \\
\text { AY828349.1, } \\
\text { AY828340.1, } \\
\text { Y828347.1, } \\
\text { AY828328.1 } \\
\text { AY828354.1, } \\
\text { AY828352.1, } \\
\text { AY828350.1, } \\
\text { AY828339.1 } \\
\text { AY828344.1 } \\
\text { AY828351.1, } \\
\text { AY828348.1 } \\
\text { AY828346.1 } \\
\text { AY828329.1 } \\
\text { DQ077808.1 }\end{array}$ & $\begin{array}{l}\text { Li \& Wilkerson (2005), } \\
\text { Linton et al (unpublished), } \\
\text { Danoff-Burg \& Conn (unpublished) }\end{array}$ \\
\hline A. nuneztovari & Nyssorhynchus & $\begin{array}{l}\text { NUN1 } \\
\text { NUN2 } \\
\text { NUN3 } \\
\text { NUN4 } \\
\text { NUN5 }\end{array}$ & $\begin{array}{l}\text { U92351.1 } \\
\text { AY028126.1, } \\
\text { AY028125.1 } \\
\text { U92350.1 } \\
\text { U92343.1 } \\
\text { AY028128.1, } \\
\text { AY028103.1, } \\
\text { AY028100.1, } \\
\text { AY028099.1, } \\
\text { AY028098.1, }\end{array}$ & $\begin{array}{l}\text { Fritz et al. (1994), } \\
\text { Marrelli et al. (2005), } \\
\text { Linton et al. (unpublished), } \\
\text { Danoff-Burg \& Conn (unpublished) }\end{array}$ \\
\hline
\end{tabular}




\begin{tabular}{|c|c|c|c|c|}
\hline Species & Subgenus & Seq. abbr. & Accession number & References \\
\hline & & & $\begin{array}{l}\text { AY028097.1, } \\
\text { AY028096.1, } \\
\text { AY028095.1, } \\
\text { AY028094.1, } \\
\text { AY028093.1, } \\
\text { AY028092.1, } \\
\text { AY028091.1, } \\
\text { AY028090.1, } \\
\text { AY028089.1, } \\
\text { AY028087.1, } \\
\text { AY028088.1, } \\
\text { AY028083.1, } \\
\text { AY028086.1, } \\
\text { AY028084.1, } \\
\text { AY028081.1, } \\
\text { AY028124.1, } \\
\text { AY028123.1, } \\
\text { AY028122.1, } \\
\text { AY028121.1, } \\
\text { AY028120.1, } \\
\text { AY028119.1, } \\
\text { AY028118.1, } \\
\text { AY028117.1, } \\
\text { AY028116.1, } \\
\text { AY028115.1, } \\
\text { AY028114.1, } \\
\text { AY028113.1, } \\
\text { AY028112.1, } \\
\text { AY028111.1, } \\
\text { AY028110.1, } \\
\text { AY028109.1, } \\
\text { AY028108.1, } \\
\text { AY028107.1, } \\
\text { AY028106.1, } \\
\text { AY028105.1, } \\
\text { AY028104.1, } \\
\text { AF461749.1, } \\
\text { AY028082.1, } \\
\text { L22462.1, } \\
\text { AY028102.1, } \\
\text { AY028101.1 }\end{array}$ & \\
\hline A. oswaldoi & Nyssorhynchus & $\begin{array}{l}\text { OSW1 } \\
\text { OSW2 } \\
\text { OSW3 } \\
\\
\\
\\
\text { OSW4 } \\
\text { OSW5 } \\
\text { OSW6 } \\
\text { OSW7 } \\
\text { OSW8 } \\
\text { OSW9 }\end{array}$ & $\begin{array}{l}\text { AF055070.1, } \\
\text { AF056318.1 } \\
\text { AF055069.1 } \\
\text { AY679154.1, } \\
\text { AY679150.1, } \\
\text { AY679149.1, } \\
\text { AY679152.1, } \\
\text { AY679155.1, } \\
\text { AY679153.1, } \\
\text { AY679151.1 } \\
\text { AF055072.1 } \\
\text { AF055071.1 } \\
\text { AF055068.1 } \\
\text { U92352.1, } \\
\text { U92344.1 } \\
\text { AF056317.1 } \\
\text { U92353.1 }\end{array}$ & $\begin{array}{l}\text { Marrelli et al. (1999), } \\
\text { Ruiz et al. (2005), } \\
\text { Danoff-Burg \& Conn (unpublished) }\end{array}$ \\
\hline A. rangeli & Nyssorhynchus & $\begin{array}{l}\text { RAN1 } \\
\text { RAN2 } \\
\text { RAN3 }\end{array}$ & $\begin{array}{l}\text { U92329.1, } \\
\text { Y09239.1 } \\
\text { AF462381.1 } \\
\text { AF462382.1 }\end{array}$ & $\begin{array}{l}\text { Fritz (1998), } \\
\text { Marrelli et al. (2005), } \\
\text { Danoff-Burg \& Conn (unpublished) }\end{array}$ \\
\hline
\end{tabular}




\begin{tabular}{lllll}
\hline Species & Subgenus & Seq. abbr. & Accession number & References \\
\hline A. rondoni & Nyssorhynchus & RON1 & U92330.1 & Danoff-Burg \& Conn (unpublished) \\
A. strodei & Nyssorhynchus & STRO1 & Y09241.1 & Fritz (1998), \\
& & STRO2 & U92354.1 & Danoff-Burg \& Conn (unpublished) \\
& STRO3 & U92345.1 & \\
A. triannulatus & Nyssorhynchus & TRIA1 & U92331.1 & Marrelli et al. (2005), \\
& & TRIA2 & AF462377.1 & Danoff-Burg \& Conn (unpublished) \\
A. trinkae & Nyssorhynchus & TRIN1 & Y09075.1 & Fritz (1998), \\
& & TRIN2 & U92355.1 & Danoff-Burg \& Conn (unpublished) \\
\hline
\end{tabular}

$a$ : sequences indicated as (unpublished) are available in the GenBank but have not been published as part of a scientific article or report.

TABLE III

Intraspecific variations of the second internal transcribed spacer (ITS2) of nuclear ribosomal DNA of Latin American Anopheles mosquitoes, according to published data

\begin{tabular}{lcc}
\hline Species & $\begin{array}{c}\text { Number of } \\
\text { different } \\
\text { sequences }\end{array}$ & $\begin{array}{c}\text { Intraspecific } \\
\text { divergence } \\
(\%)\end{array}$ \\
\hline Anopheles crucians & 5 & 14.0 \\
Anopheles quadrimaculatus & 4 & 2.4 \\
Anopheles cruzii & 4 & 0.3 \\
Anopheles albimanus & 2 & 0.4 \\
Anopheles albitarsis & 3 & 0.2 \\
Anopheles aquasalis & 15 & 1.9 \\
Anopheles argyritarsis & 4 & 3.0 \\
Anopheles benarrochi & 4 & 19.0 \\
Anopheles darlingi & 4 & 5.7 \\
Anopheles deaneorum & 3 & 2.5 \\
Anopheles dunhami & 2 & 8.8 \\
Anopheles evansae & 3 & 13.0 \\
Anopheles konderi & 3 & 0.3 \\
Anopheles rangeli & 3 & 0.3 \\
Anopheles strodei & 3 & 8.0 \\
Anopheles triannulatus & 2 & 0.2 \\
Anopheles trinkae & 2 & 0.3 \\
Anopheles marajoara & 7 & 15.0 \\
Anopheles oswaldoi & 8 & 18.0 \\
Anopheles nuneztovari & 5 & 0.3 \\
\hline
\end{tabular}

by the Neighbour Joining algorithm and number of differences) using the MEGA software (Molecular Evolutionary Genetics Analysis, version 3.01) (Kumar et al. 2003). The sequences were aligned using the CLUSTAL W software (1.60) (Thompson et al. 1994). To obtain a better alignment, both pairwise and multiple alignments parameters were changed from the default set: DNA substitution matrix from the Clustal program, decreased the open gap penalty to 10 , and also decreased the transition/transversion rate to 0.25 . The ITS2 sequences were clustered into three major clades that represent the three subgenera, Nyssorhynchus, Kerteszia, and Anopheles. Although Anopheles and
Kerteszia subgenera have fewer species and ITS2 sequences represented in this study, as compared to the Nyssorhynchus subgenus, the three groups formed are compatible with the morphological hypothesis of classification of the genus Anopheles. Based on their ITS2 sequences, Nyssorhynchus and Kerteszia mosquitoes grouped together in a major phylogenic branch (Fig. 1-a) supporting the Nyssorhynchus and Kerteszia monophyletic lineage previously proposed (Sallum et al. 2000, Krzywinski et al. 2001a, b).

\section{SUBGENUS KERTESZIA}

Kerteszia is a small Neotropical subgenus of Anopheles, composed of only 12 species (Zavortink 1973, Collucci \& Sallum 2003), with a geographic distribution extending from South of Mexico to the state of Rio Grande do Sul in Brazil (Aragão 1964). A. cruzii and A. bellator were the primary vectors of the once malaria endemic area in Southeastern and Southern Brazil (Rachou 1958). Up to now, however, these species have been involved in the transmission of malaria to human populations that live in close association with the Atlantic Forest (Deane 1988, Branquinho et al. 1997, Machado et al. 2003).

Of the four Kerteszia species having available ITS2 sequences, the NJ tree shows that the ITS2 sequences of A. cruzii cluster in a single clade (Fig. 1-b). Four different ITS2 sequences assigned to organisms identified as $A$. cruzii exist in the data base. These four sequences could either represent intraspecific polymorphism or the existence of a complex of sibling species yet to be described. Specimens of $A$. cruzii also have been analyzed on the basis of their polytene chromosome patterns (Ramirez \& Dessen 2000 a,b) providing evidence for genetically distinct populations, and suggesting an ongoing process of speciation within this group of mosquitoes. Future studies should verify if there is a correlation between the chromosomal forms and the distinct ITS2 sequences. The placement of $A$. laneanus next to $A$. cruzii (Fig. 1-c) is consistent with the interpretation that these two species belong to a group that includes A. cruzii, A. laneanus and possibly other unnamed new species. A. laneanus is an endemic species of the Serra da Mantigueira, Southern Brazil, and is 
morphologically more similar in all life stages to $A$. cruzii than to any other Kerteszia species. Characters that separate these two species are mainly those of the male genitalia. The Kerteszia subgenus and the presumed A. cruzii complex deserve further investigation, since they include human malaria vectors. The present situation in Southern Brazil, where malaria parasites and vectors coexist alongside developed and highly populated areas, demands constant surveillance from public health authorities to prevent epidemic episodes.

\section{SUBGENUS ANOPHELES}

The ITS2 sequences of mosquitoes of the subgenus Anopheles (11 species) cluster together (Fig. 1-d). As mentioned above, several malaria vectors belonging to this group do not have ITS2 sequences available. All ITS2 sequences generated from A. quadrimaculatus grouped together (Fig. 1-e). A. quadrimaculatus belongs to the Quadrimaculatus Subgroup and the samples are clustered with three species of the Freeborni Subgroup ( $A$. freeborni, A. hermsi, and A. occidentalis) (Fig. 1-f). Both subgroups belong to the Maculipennis Group. The Crucians Complex of the Punctipennis Subgroup includes A. crucians, A. bradleyi, A. georgianus, and four informally designated species. Except for the sequence CRUC3 that was recovered within the clade leading to species of the Maculipennis Group, the remaining four A. crucians plus BRAD1 sequences clustered together, reflecting their relative positions determined by classical taxonomy (Fig. 1-g). Wilkerson et al. (2004) subdivided the North American specimens of the taxon A. crucians into A. crucians species A, B, C, D, and E (here designated CRUC1-5) based on rDNA ITS2 sequence data. Further investigation is needed to determine if $A$. crucians from Latin America belongs to those previously described species. The placement of $A$. bradleyi (BRAD1) within the A. crucians Group could indicate that gene flow occurs among these two closely-related species. However, this hypothesis has already been tested and discarded by the analysis of the progeny of $A$. bradleyi and A. crucians intraspecific crosses (Kreutzer \& Kitzmiller 1971).

A. mediopunctatus and A. fluminensis, both of the Arribalzagia Series (Wilkerson \& Peyton 1990) are grouped together, however, A. peryassui and $A$. mattogrossensis of the same series were placed in different branchs of the tree. A. eiseni and A. pseudopunctipennis, both of the Pseudopunctipennis Group were placed in distinct clades (Fig. 1-h). These molecular data do not support the classic systematic placement of the group, however, it is important to consider that only one ITS2 sequence is available for each one of these five species. While the sequences may have some taxonomic value, evolutionary inferences could not be derived from such a small sample.

\section{SUBGENUS NYSSORHYNCHUS}

The subgenus Nyssorhynchus comprises 33 species (Harbach 2004) that are largely known to be problematic for identification using only female morphological characters, mainly due to their intraspecifc variation and interspecific similarity (Hribar 1995, 1997). It is worth noting that several of the ITS2 sequences presently available in the GenBank were generated from DNA extracted from field captured female specimens and this could lead to misidentification as discussed in the following paragraphs. Male genitalia traits are generally less variable (Faran 1980, Linthicum 1988), however, sometimes they lack elements for species identification or may vary geographically (Hribar 1994). Consequently other life stages need to be examined as well. The external morphology of the eggs also has been investigated in order to provide species-diagnostic characters (Lounibos et al. 1998). Forattini et al. (1998) showed that this character is polymorphic among populations of a single species and Deane and Causey (1943) provided evidence that the eggshell morphology could vary according to environmental conditions. Therefore, the external morphology of the egg also should be used cautiously when distinguishing between closely-related species.

Identification difficulties are not evident for all the Nyssorhynchus species. Some species of the Nyssorhynchus subgenus are easily distinguishable by morphological characters and ITS2 sequences. Hence, all 15 sequences from $A$. aquasalis were recovered in a single clade, and so were four from $A$. darlingi, four from $A$. argyritarsis, three from $A$. trinkae, two from $A$. triannulatus, and three from $A$. rangeli specimens (Fig. $1-\mathrm{i}, \mathrm{j}, \mathrm{k}, \mathrm{l}, \mathrm{m}, \mathrm{n})$. In contrast, other species are not easily discernible from each other and their ITS2 sequences were placed in more than one group of the NJ tree.

The $A$. albitarsis complex includes $A$. albitarsis $s$. s., A. marajoara, A. deaneorum, and an unnamed species designated A. albitarsis B (Wilkerson et al. 1995). Lehr et al. (2005), using data derived from the sequences of the cytochrome c oxidase subunit I (COI) gene, hypothesized a fifth species in this complex, designated species E, which occurs in Boa Vista municipality, state of Roraima, Brazil. Species included in the A. albitarsis complex are notoriously difficult to identify. Their external morphology is similar in all life stages with interspecific and intraspecific variation. A. deaneorum can be distinguished from other species only by the larval seta 3-C, which is branched in A. deaneorum, whereas it is single in the remaining species. In the adult stage, $A$. deaneorum can be distinguished by the absence of posterolateral scales on abdominal segment III. Both traits are difficult to evaluate and need well-preserved samples. Morphology traits for separating A. marajoara, A. albitarsis, and A. albitarsis $\mathrm{B}$ are more problematic and may overlap among the species. Wilkerson et al. (1995) noted that the extent of dark pigmentation on the hindtarsus 2 could be used to distinguish $A$. albitarsis and $A$. albitarsis $\mathrm{B}$. The former species has more than 0.5 basal dark, while $A$. albitarsis $\mathrm{B}$ has less than 0.5 . However, if this is correct $A$. albitarsis overlaps $A$. marajoara in which the basal dark varies from 0.6-0.9 length of segment. Members of the A. albitarsis complex are apparently largely allopatric. According to $\mathrm{Li}$ and Wilkerson (2005), A albitarsis occurs in Southern Brazil, Northern Argentina, and Paraguay, A. deaneorum 
in Northern Argentina and Western Brazil, A. albitarsis $\mathrm{B}$ in South, Central, and Eastern Brazil, A. marajoara in Brazil, Venezuela, Colombia, Southern Central America, and $A$. albitarsis $\mathrm{E}$ is restrict to Northern Amazonas River. Even with that information, geographical distribution of members of the A. albitarsis complex is poorly described, especially along the Brazilian coast and savannah where few captures have been performed, and there are no specimens from those areas available in collections for study. In conclusion, discriminating among species of the A. albitarsis complex based on either morphology or molecular markers is still problematic (Wilkerson et al. 1995, Lehr et al. 2005). Accordingly, we found the ITS2 sequences of $A$. marajoara, A. deaneorum, and $A$. albitarsis distributed in more than one group of the tree (Fig. 1-o). This pattern could indicate large intraspecific variations of the ITS2 sequences, a recent process of speciation within this group, or could represent the misidentification of the specimens that had their DNA extracted and sequenced. Recent advances reported by Li and Wilkerson (2005) indicate that the polymerase chain reaction technique with a set of species-specific oligonucleotide primers enables the separation of four species of the A. albitarsis complex, except species E. Nevertheless, further efforts to clarify the taxonomic status of these mosquitoes are being made and the morphology of $A$. albitarsis species $\mathrm{E}$ is being evaluated by Motoki et al. (unpublished results).

Marrelli et al. (1999) analyzing the ITS2 from specimens identified as $A$. oswaldoi found four distinct sequences and hypothesized that at least one of these could be from A. konderi. Morphological distinction between $A$. konderi and $A$. oswaldoi is based on the shape

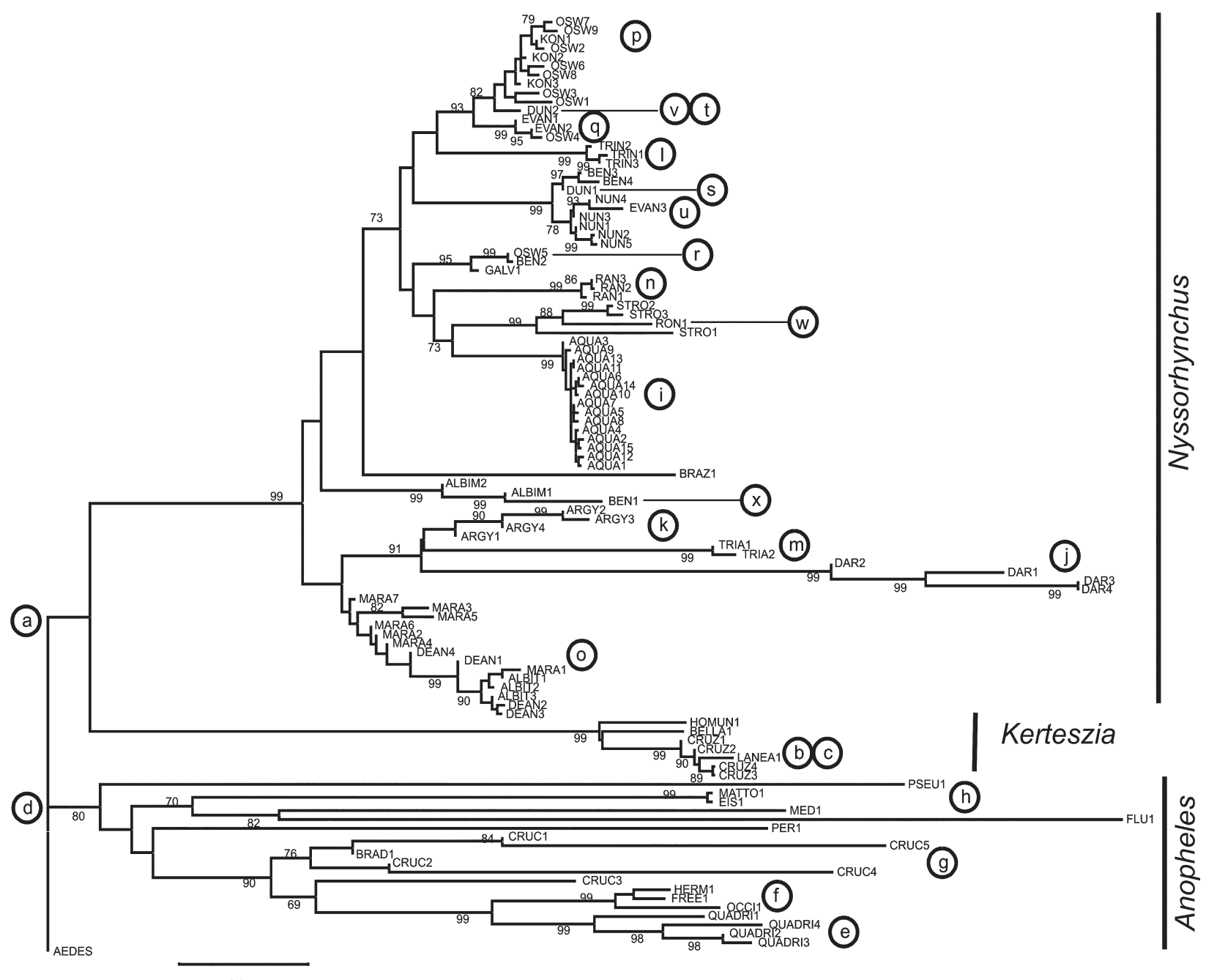

20

Fig. 1: Neighbor-Joining bootstrap tree based on the second internal transcribed spacer (ITS2) of the nuclear ribosomal DNA genes from Latin American Anopheles mosquitoes. The tree was rooted with Aedes aegypti ITS2 sequence (GenBank/EMBL: M95126). Numbers above the branches show bootstrap confidence levels (from 1000 replications) for the split. Bootstrap values lower than 70 were omitted in the figure. Species names abbreviated as in Table I. The grouping of the species belonging to each subgenus is indicated in the right of the figure. Letters (a-x) indicate the positions of the sequences discussed in the text. Aligned sequences (Clustal W) were examined with the MEGA software (Molecular Evolutionary Genetics Analysis, version 3.01). Sequences alignment and an alternative tree by Maximum Parsimony method are available upon request to the authors. 
of the apical area of the aedeagus of the male genitalia (Causey et al. 1946). Because the type locality of the former species is Coari (Rio Solimões, state of Amazonas, Brazil) it is reasonable to consider that the specimen that Marrelli et al. (1999) collected in the state of Amazonas is in fact A. konderi. Except for OSW4 and OSW5, most sequences of specimens identified as A. oswaldoi and A. konderi clustered in a major clade (Fig. 1-p). Further studies need to be performed to determine if there is a true overlap of ITS2 sequences of A. oswaldoi and A. konderi or the present data is due to misidentification of specimens. Interestingly, the OSW4 sequence generated from a specimen captured in Vale do Rio Doce, Espírito Santo, Brazil, which was identified as An. oswaldoi by Marrelli et al. (1999) grouped with EVAN1 and EVAN2 (Fig. 1-q), whereas OSW5 isolated from specimen collected in Peru appeared in a clade formed by sequences of $A$. galvaoi and $A$. benarrochi (BEN2) (Fig. 1-r). Position of an A. oswaldoi sequence in a cluster with two $A$. evansae sequences suggests that the specimen identified as $A$. oswaldoi (OSW4) was misidentified. Morphological separation of adult females of $A$. evansae and A. oswaldoi is based mainly on the basal dark band of the hindtarsal segment 2 which is usually $<0.25(0.12-0.25)$ the length of segment in $A$. oswaldo $i$ and $A$. konderi or $\geq 0.25$ the length of segment in A. evansae $(0.2-0.4)$. In addition to the hindtarsus 2 , Faran (1980) pointed out the ratio between the humeral light spot and basal dark spot of wing vein $\mathrm{C}$ that in $A$. oswaldo $i$ varies from 1.10 to 3.80 , while in $A$. evansae is $1.75-4.5$. In summary, these characters are polymorphic and overlap between the two species. Therefore, the proper identification of these mosquitoes requires a wide-ranging study of how characters vary in distinct population of each species and the observation of maleassociated characters. Male genitalia aedeagus clearly distinguish $A$. evansae and $A$. oswaldoi indicating that the analyses of male progeny of captured females is necessary to solve these impasses.

Morphological separation between A. oswaldoi, A. galvaoi, and $A$. benarrochi may be problematic when using only adult female traits (Sallum et al. 2002), and thus we believe that some of the specimens that generated the cluster containing BEN2, GALV1, and OSW5 sequences (Fig. 1-r) could have been misidentified. Quiñones et al. (2001), Calle et al. (2002), and Estrada et al. (2003) noted that some individuals of $A$. benarrochi from Southern Colombia can be misidentified as either A. evansae or A. oswaldoi due to overlapping characters when using female morphology. A. evansae, $A$. oswaldoi, and A. benarrochi can be easily distinguished based on male genitalia traits. The occurrence of $A$. benarrochi in the state of São Paulo, Brazil (Sallum et al. 1997) is suggestive that this population differs from that of the type locality, which is in La Ceiba, Trujillo Department, Venezuela. ITS2, as well as other molecular markers could be informative about similar and/or differential characters among $A$. benarrochi populations from distinct geographic origins. Populations of $A$. benarrochi of São Paulo are currently been investigated, and there are morphological evidences that distinguish São Paulo form from that illustrated by Faran (1980) (Sallum et al. unpublished results).

The ITS2 sequences of $A$. dunhami specimens also are problematic. One sequence, DUN1 groups with $A$. benarrochi (BEN3 and BEN4, both from specimens collected in the state of Rondonia, Brazil), whereas DUN2 (specimen collected in the state of Acre) clusters within the A. oswaldoi group (Fig. 1-s,t). The geographical distribution of $A$. dunhami is poorly known. Currently, this species was registered in Tabatinga and Tefé (type-locality) both in Amazonas, Brazil. The fact that DUN1 clusters with BEN3 and BEN4 raises a question about the presence of An. dunhami in Rondonia. However, this hypothesis might be tested by generating sequences from specimens correctly identified. The adult female of $A$. dunhami is morphologically more similar to A. nuneztovari than to any other Nyssorhynchus species, however both species can be misidentified as either A. oswaldoi or A. evansae when using only female traits. Characters of the hindtarsomere 2 and the ratio of humeral light spot and basal dark spot, although distinct among those species, vary and may overlap among distinct populations and consequently makes species separation more difficult. For example, the placement of $A$. evansae among sequences generated from specimens identified as A. nuneztovari (Fig. 1-u) and A. oswaldoi (Fig. 1-q), and that of A. dunhami within the A. oswaldoi group (Fig. 1-v) makes it reasonable to conclude that a specimen of $A$. nuneztovari has been misidentified as $A$. evansae (EVAN3), and DUN2 belongs, in fact, to a specimen of a taxa of the $A$. oswaldoi Group. Distinction between $A$. evansae and $A$. nuneztovari is based mainly on ratio of lengths of the vein $\mathrm{C}$ humeral light spot and basal dark spot, which is $<2.0$ in A. nuneztovari but $\geq 2.0$ in A. evansae. However, Hribar (1995) showed that variation occur within and among isofemale progeny lines of A. nuneztovari from distinct geographic localities, and thus they could be misidentified as other species, i.e. A. evansae when that value is $>2$. Consequently, the presence of $A$. dunhami in Acre state needs to be confirmed.

Wilkerson et al. (1990) have determined that $A$. rondoni can be easily distinguished from other species based on the dark spot of the prescutellar area, which is well developed in $A$. rondoni, however a character frequently used for identification of $A$. rondoni is a dark basal band on hindtarsome 3 . It is important to note that this dark band is absent in some individuals of this species and thus $A$. rondoni can be misidentified if the dark spot in the prescutellar area is not taken into consideration. The position of the RON1 sequence within the A. strodei group (Fig. 1-w) suggests that either the sample used for generating the ITS2 sequence was misidentified as $A$. rondoni or that $A$. strode $i$ may be a species complex. Moreover, Sallum et al. (unpublished results) found strong morphological evidences that there are two distinct forms of $A$. strodei in São Paulo. This is going to be tested by sequencing specimens of both forms. 
The placement of BEN1 among sequences of specimens of A. albimanus (Fig. 1-x) is probably due to misidentification or mislabeling of that specimen (BEN1) because the species can be easily separate using female external morphology (see Faran 1980, for morphological details).

\section{CONCLUDING REMARKS}

We have reviewed the available ITS2 sequences from Latin American anophelines and antecipate that it will further stimulate needed research in malaria vector taxonomy. The analyses indicate that ITS2 provides valuable molecular markers that could be applied for the identification of some species and also could be used to further investigate population genetics and the occurrence of sibling species of Latin America anophelines. Although morphological characters are available to identify most of the studied species, the distinction of closely-related species may be problematic, and additional differential traits must be utilized. DNA-based methods are advantageous in these cases because they can be applied to specimens and situations unsuitable for morphological taxonomy. For example, DNA may be obtained and analyzed from specimens in all developmental stages, of both sexes, fresh, preserved in alcohol, dried or frozen.

One possibility that has emerged from this comprehensive analysis is that because of the difficulties in precise identification of field captured female specimens based only on their morphological characters, a number of them could have been misidentified and therefore their corresponding ITS2 sequences were deposited into GenBank with incorrect organism source assignment. Unfortunately, most of the publications regarding the ITS2 sequences from Neotropical anophelines do not provide indications that siblings of the analyzed specimen are preserved and available for further morphological and/or molecular verification. Therefore, those questionable sequences can not be reevaluated and validated, or have their records corrected. In conclusion, while research in malaria vector taxonomy has profited from data provided by single or few field captured mosquitoes, the problems pointed out in the preceding paragraphs indicate that caution should be taken and a minimum of requirements should be considered by researchers working with Latin American anophelines in the design of future studies. Following we outline basic characteristics of taxonomic studies in order to continue producing reliable and high-quality results that will provide basis for effective surveillance and control strategies in the countries where malaria occurs. We propose that:

1) Voucher specimens need to be deposited in collections (Museums) - The progeny of field captured female mosquitoes can usually be raised in the laboratory. DNA could then be extracted from some of the siblings of the family while other specimens should be preserved to allow future verification. DNA sequences should be of high quality and attached to a voucher specimen whose origin and current status are registered. The placement of samples in repository institutions will serve as a platform to ensure preservation of specimens and communication between repositories and researchers (Hebert \& Gregory 2005, Corthals \& Desalle 2005)

2) Intraspecific variation should be considered Species identification either needs to be based on invariant characters, or the variability of the characters determined among the individuals of the species. Larger samples composed of several specimens from each locality, and from distinct localities covering the known geographic distribution of the species, should be analyzed. Furthermore, intragenomic heterogeneity may occur, and in those circunstances direct sequencing of PCR products may be misleading. Intragenomic polymorphism occurring, cloning of PCR products and sequencing of individual clones from each specimen is required. Unfortunately, due to the cost and timeconsuming mosquito captures, researchers are sometimes reluctant to perform these large scale studies, incurring the risk of proposing or defining species complexes without an adequate evaluation of intraspecific variation (van Bortel \& Coosemans, 2003). As an example, Fairley et al. (2005) detected 15 different A. aquasalis ITS2 sequences ( 72 clones examined) from mosquito samples from two geographic locations in Brazil, two in Venezuela, and one in Suriname. The observed intraspecific divergence could suggest a complex of species, nevertheless that accurate study led to the conclusion that the nucleotide variations were not informative in distinguishing populations, supporting the status of $A$. aquasalis as a single species.

3) Other molecular markers should be used in addition to ITS2 - Molecular biological techniques are becoming readily available in most scientific institutions and the cost of DNA sequencing is no longer prohibitive. ITS2 is only one of the molecular markers, therefore, once the DNA has been extracted from mosquito specimens, a wealth of information could be generated, including the sequences of other marker genes such as those of the nuclear and mitochondrial ribosomal loci (ITS1 and IGS) and mitochondrial genomes (COI, COII). Random amplified polymorphic DNA (RAPD) and restriction fragment length polymorphic (RFLP) markers as well as microsatellite DNAs could also be utilized to distinguish between anopheline species (Norris 2002).

4) Additional biological data are necessary Laboratory autonomous colonies of most of the Neotropical anophelines, including some of the major malaria vectors such as $A$. darlingi, are still unavailable. Efforts should be made to colonize these mosquitoes and this would facilitate the acquisition of biological data that nowadays are only possible through time-consuming and costly field captures. These colonies also would be beneficial in providing the opportunity of performing mating compatibility studies between specimens of potential sibling species (Lima et al. 2004 a,b). Cytogenetics has proven immensely useful for differentiating among sympatric anopheline taxa, however, 
with a few exceptions (Pérez \& Conn 1992, Ramirez \& Dessen $2000 \mathrm{a}, \mathrm{b}$ ), this technique has not been applied for neotropical anophelines. Ecological (Guimarães et al. 2004), behavioral (da Silva Vasconcelos et al. 2002) and biochemical (Phillips et al. 1988, dos Santos et al. 2003) studies also provide important information for mosquito taxonomy and should be encouraged.

5) A mosquito integrative taxonomy is valuable and desirable - Molecular markers are to support and not replace traditional taxonomy. The value of molecular markers is most powerful in disclosing hidden diversity when coupled with traditional taxonomic tools. The continuous generation of quality data and the application of an integrative taxonomy, which uses all available characters including DNA sequences and other types of data, to delimit, discover, and identify meaningful, natural species and taxa (Faran 1979, Rubio-Palis \& Zimmerman 1997, Lounibos \& Conn 2000, Will et al. 2005) will contribute to a more detailed understanding of the anophelines species and complexes in Latin America and serve as a basis for effective malaria vector control programs in this part of the world.

\section{ACKNOWLEDGEMENTS}

To Dr Anthony A James and Dr Olle Terenius for comments and critical reading of the manuscript.

\section{REFERENCES}

Aragão MB 1964. Distribuição geográfica e abundância das espécies de Anopheles (Kerteszia) (Diptera: Culicidae). Rev Bras Malariol Doenças Trop 16: 73-109.

Beebe NW, Bakote'e B, Ellis JT, Cooper RD 2000. Differential ecology of Anopheles punctulatus and three members of the Anopheles farauti complex of mosquitoes on Guadalcanal, Solomon Islands, identified by PCR-RFLP analysis. Med Vet Entomol 14: 308-312.

Black IV WC, Munstermann LE 2005. Molecular taxonomy and systematic of arthropod vectors. In WC Marquardt, Biology of Disease Vectors, Elsevier Academic Press, Burlington, $\mathrm{p}$. 505-528.

Branquinho MS, Araújo MS, Natal D, Marrelli MT, Rocha MR, Taveira FAL, Kloetzel JK 1996. Anopheles oswaldoi a potential malaria vector in Acre, Brazil. Trans R Soc Trop Med Hyg 90: 233.

Branquinho MS, Marrelli MT, Curado I, Natal D, Barata JM, Tubaki RM, Carrerri-Bruno MG, de Menezes RT, Kloetzel JK 1997. Infecção de Anopheles (Kerteszia) cruzii por Plasmodium vivax e Plasmodium vivax variante VK247 nos municípios de São Vicente e Juquitiba, São Paulo. Rev Panam Salud Publica 2: 189-193.

Branquinho MS, Taipe-Lagos CB, Rocha RM, Natal D, Barata JMS, Cochrane AH, Nardin E, Nussenzweig RS, Kloetzel JK 1993. Anophelines in the State of Acre, Brazil, infected with Plasmodium falciparum, $P$. vivax, the variant $P$. vivax VK247 and P. malariae. Trans R Soc Trop Med Hyg 874: 391-394.

Besansky NJ, Powell JR, Caccone A, Hamm DM, Scott JA, Collins FH 1994. Molecular phylogeny of the Anopheles gambiae complex suggests genetic introgression between principal malaria vectors. Proc Natl Acad Sci USA 91: 68856888.
Calderón G, Fernández R, Valle J 1995. Especies de la fauna anofelina, su distribuición y algunas consideraciones sobre su abundancia e infectividad en Perú. Rev Perú Epidemiol 8: 5-23.

Calle LDA, Quiñones ML, Erazo HF, Jaramillo ON 2002. Morphometric discrimination of females of five species of Anopheles of the subgenus Nyssorhynchus from Southern and Northwest Colombia. Mem Inst Oswaldo Cruz 97: 11911195 .

Carvajal H, de Herrera MA, Quintero J, Alzate A, Herrera S. 1989. Anopheles neivai: a vector of malaria in the Pacific lowlands of Colombia. Trans R Soc Trop Med Hyg 83: 609.

Carvalho-Pinto CJ, Lourenço-de Oliveira R 2004. Isoenzimatic analysis of four Anopheles (Kerteszia) cruzii (Diptera: $\mathrm{Cu}-$ licidae) populations of Brazil. Mem Inst Oswaldo Cruz 95: 471-475.

Causey OR, Deane, LM, Deane MP 1946. Studies on the Brazilian anophelines from the Northeast and Amazon regions II. An illustrated key by male genitalia characteristics of the Anophelini, with a noteon dissection technique. Am J Trop Med Hyg (Monograph series) 18: 21-34.

Coetzee M 2006. Malaria and dengue vector biology and control in Southern and Eastern Africa. In BGJ Knols, C Louis (eds), Bridging Laboratory and Field Research for Genetic Control of Disease Vectors, Wageningen UR Frontis Series, Springer, Dordrecht, p. 101-110.

Coetzee M, Craig M, le Sueur D 2000. Distribution of African malaria mosquitoes belonging to the Anopheles gambiae complex. Parasitol Today 16: 74-77.

Collins FH, Paskewitz SM 1996. A review of the use of ribosomal DNA (rDNA) to differentiate among cryptic Anopheles species. Insect Mol Biol 5: 1-9.

Collucci E, Sallum MAM 2003. Phylogenetic analysis of the subgenus Kerteszia of Anopheles (Diptera: Culicidae: Anophelinae) based on morphological characters. Insect Syst Evol 34: 361-372.

Coluzzi M 1966. Osservazione comparative sul cromosoma X nelle specie A e B del complesso An. gambiae. Rend Accad Naz Lincei 40: 671-678.

Conn JE, Wilkerson RC, Segura MN, de Souza RT, Schlichting CD, Wirtz RA, Povoa MM 2002. Emergence of a new neotropical malaria vector facilitated by human migration and changes in land use. Am J Trop Med Hyg 66: 18-22.

Consoli RAGB, Lourenço-de-Oliveira R 1994. Principais Mosquitos de Importância Sanitária no Brasil, Fiocruz, Rio de Janeiro, 225 pp.

Cornel AJ, Porter CH, Collins FH 1996. Polymerase chain reaction species diagnostic assay for Anopheles quadrimaculatus cryptic species (Diptera: Culicidae) based on ribosomal DNA ITS2 sequences. J Med Entomol 33: 109116.

Corthals A, Desalle R 2005. An application of tissue and DNA banking for genomics and conservation: The Ambrose Monell cryo-collection (AMCC). Syst Biol 54: 819-823.

Crampton JM, Hill SM 1997. Generation and use of speciesspecific DNA probes for insect vector identification. In JM Crampton, CB Beard, C Louis (eds), The Molecular Biology of Insect Disease Vectors, Chapman \& Hall, London, p. 384-398. 
da Silva-Vasconcelos A, Kato MY, Mourão EN, de Souza RT, Lacerda RN, Sibajev A, Tsouris P, Povoa MM, Momen H, Rosa-Freitas MG 2002. Biting indices, host-seeking activity and natural infection rates of anopheline species in Boa Vista, Roraima, Brazil from 1996 to 1998. Mem Inst Oswaldo Cruz 97: 51-61.

de Arruda M, Carvalho MB, Nussenzweig RS, Maracic M, Ferreira AW, Cochrane AH 1986. Potential vectors of malaria and their different susceptibility to Plasmodium falciparum and Plasmodium vivax in northern Brazil identified by immunoassay. Am J Trop Med Hyg 35: 873-881.

de Oliveira-Ferreira J, Lourenço-de-Oliveira R, Teva A, Deane LM, Daniel-Ribeiro CT 1990. Natural malaria infections in anophelines in Rondonia State, Brazilian Amazon. Am J Trop Med Hyg. 43: 6-10.

Deane LM 1986. Malaria vectors in Brazil. Mem Inst Oswaldo Cruz 81: 5-14.

Deane LM 1988. Malaria studies and control in Brazil. Am J Trop Med Hyg 38: 223-230.

Deane MP, Causey OR 1943. Viability of Anopheles gambiae eggs and morphology of unusual types found in Brazil. Am J Trop Med 23: 95-103.

dos Santos JM, Maia J de F, Tadei WP, Rodriguez GA 2003. Isoenzymatic variability among five Anopheles species belonging to the Nyssorhynchus and Anopheles subgenera of the Amazon region, Brazil. Mem Inst Oswaldo Cruz 98: 247253.

Estrada DA, Quiñones ML, Sierra DM, Calle DA, Ruiz F, Erazo HF, Linton YM 2003. Egg morphology as an indirect method to identify Anopheles benarrochi, Anopheles oswaldoi and Anopheles rangeli (Diptera: Culicidae). Biomedica 23: 388395.

Fairley TL, Kilpatrick CW, Conn JE 2005. Intragenomic heterogeneity of internal transcribed spacer rDNA in neotropical malaria vector Anopheles aquasalis (Diptera: Culicidae). J Med Entomol 42: 795-800.

Faran ME 1979. The importance of an integrated approach in solving a problem in mosquito systematics. Mosq Syst 11: 280-288.

Faran ME 1980. Mosquito studies (Diptera: Culicidae) XXXIV. A revision of the Albimanus Section of the subgenus Nyssorhynchus of Anopheles. Contrib Amer Entomol Inst (Ann Arbor) 15: 1-215.

Faran ME, Linthicum KJ 1981. A handbook of the Amazonian species of Anopheles (Nyssorhynchus) (Diptera: Culicidae). Mosq Syst 13: 1-81.

Flores-Mendoza C, Fernandez R, Escobedo-Vargas KS, VelaPerez Q, Schoeler GB 2004. Natural Plasmodium infections in Anopheles darlingi and Anopheles benarrochi (Diptera: Culicidae) from eastern Peru. J Med Entomol 41: 489-494.

Forattini OP, Kakitani I, Santos RL, Ueno HM, Kobayashi KM 1999. Role of Anopheles (Kerteszia) bellator as malaria vector in southeastern Brazil (Diptera: Culicidae). Mem Inst Oswaldo Cruz 94: 715-718.

Forattini OP, Sallum MA, Bergo ES, Flores DC 1998. Ultrastructure of eggs of Anopheles rondoni, Anopheles lutzi, and Anopheles parvus, three species of the subgenus Nyssorhynchus. J Am Mosq Control Assoc 14: 256-265.
Fritz GN 1998. Sequence analysis of the rDNA internal transcribed spacer 2 of five species of South American human malaria mosquitoes. DNA Seq 8: 215-221.

Fritz GN, Conn J, Cockburn A, Seawright J 1994. Sequence analysis of the ribosomal DNA internal transcribed spacer 2 from populations of Anopheles nuneztovari (Diptera: Culicidae). Mol Biol Evol 11: 406-416.

Fritz GN, Engman S, Rodriguez R, Wilkerson RC 2004. Identification of four vectors of human Plasmodium spp. by multiplex PCR: Anopheles rangeli, A. strodei, A. triannulatus, and A. trinkae (Diptera: Culicidae: Nyssorhynchus). J Med Entomol 41: 1111-1115.

Frizzi G 1947. Cromosomi salivari in Anopheles maculipennis. Sci Genet (Torino) 3: 67.

Frizzi G 1953. Étude cytogénétique d'Anopheles maculipennis en Italie. Bull WHO 9: 335.

Goswami G, Raghavendra K, Nanda N, Gakhar SK, Subbarao SK 2005. PCR-RFLP of mitochondrial cytochrome oxidase subunit II and ITS2 of ribosomal DNA: markers for the identification of members of the Anopheles culicifacies complex (Diptera: Culicidae). Acta Trop 95: 92-99.

Grieco JP, Achee NL, Roberts DR, Andre RG 2005. Comparative susceptibility of three species of Anopheles from Belize, Central America, to Plasmodium falciparum (NF-54). J Am Mosq Control Assoc 21: 279-290.

Guimarães AE, Gentile C, Alencar J, Lopes CM, de Mello RP 2004. Ecology of Anopheline (Diptera, Culicidae), malaria vectors around the Serra da Mesa Reservoir, State of Goiás, Brazil. 1-Frequency and climatic factors. Cad Saúde Púb 20:291-302.

Harbach RE 2004. The classification of genus Anopheles (Diptera: Culicidae): a working hypothesis of phylogenetic relationships. Bull Entomol Res 94: 537-553.

Hayes J, Calderon G, Falcon R, Zambrano V 1987. Newly incriminated anopheline vectors of human malaria parasites in Junin Department, Peru. J Am Mosq Control Assoc 3: 418422 .

Hebert PDN, Gregory TR 2005. The promise of DNA barcoding for taxonomy. Syst Biol 54: 852-859.

Hribar LJ 1994. Geographic variation of male genitalia of Anopheles nuneztovari Gabaldon. Mosq Syst 26: 132-144.

Hribar LJ 1995. Costal wing spot variation within and among progeny of single female Anopheles nuneztovari (Diptera: Culicidae). Mosq Syst 27: 1-15.

Hribar LJ 1997. Effect of larval rearing temperature on adult female morphology of Anopheles (Nyssorhynchus) albimanus (Diptera: Culicidae). Invertebr Reprod Dev 32: 85-88.

Huong NT, Sonthayanon P, Ketterman AJ, Panyim S 2001. A rapid polymerase chain reaction based method for identification of the Anopheles dirus sibling species. Southeast Asian J Trop Med Public Health 32: 615-620.

Jaichapor B, Kengluecha A, Rongnoparut P, Rueda LM, Jones JW, Sithiprasasna R 2005. Morphological variations of Anopheles minimus A in Tak Province, Thailand. Southeast Asian J Trop Med Public Health 36: 609-615.

Kamau L, Hawley WA, Lehmann T et al. 1998. Use of short 
tandem repeats for the analysis of genetic variability in sympatric populations of Anopheles gambiae and Anopheles arabiensis. Heredity 80: 675-682.

Kittayapong P 2006. Malaria and dengue vector biology and control in Southeast Asia. In BGJ Knols, C Louis (eds), Bridging Laboratory and Field Research for Genetic Control of Disease Vectors, Wageningen UR Frontis Series, Springer, Dordrecht, p. 111-128.

Klein TA, Lima JBP, Tada MS 1991a. Comparative susceptibility of anopheline mosquitoes to Plasmodium falciparum in Rondônia, Brazil. Amer J Trop Med Hyg 44: 598-603.

Klein TA, Lima JBP, Tada MS, Miller R 1991b. Comparative susceptibility of anopheline mosquitoes in Rondônia, Brazil, to infection by Plasmodium vivax. Am J Trop Med Hyg 45: 463-470.

Kreutzer RD, Kitzmiller JB 1971. Hybridization between Anopheles crucians and Anopheles bradleyi. Evolution 25: 193206.

Krzywinski J, Besansky NJ 2003. Molecular systematics of Anopheles: from subgenera to subpopulations. Annu Rev Entomol 48: 111-139.

Krzywinski J, Wilkerson RC, Besansky NJ 2001a. Evolution of mitochondrial and ribosomal gene sequences in anophelinae (Diptera: Culicidae): implications for phylogeny reconstruction. Mol Phylogenet Evol 18: 479-487.

Krzywinski J, Wilkerson RC, Besansky NJ 2001b. Toward understanding Anophelinae (Diptera, Culicidae) phylogeny: insights from nuclear single-copy genes and the weight of evidence. Syst Biol 50: 540-556.

Kumar S, Tamura K, Nei M 2003. MEGA: molecular evolutionary genetics analysis, ver. 1.01. The Pennsylvania State University, University Park, Penn.

Lehr MA, Kilpatrick CW, Wilkerson RC, Conn JE 2005. Cryptic species in the Anopheles (Nyssorhynchus) albitarsis (Diptera: Culicidae): incongruence between random amplified polymorphic DNA-polymerase chain reaction identification and analysis of mitochondrial DNA COI gene sequence. Ann Entomol Soc Amer 98: 908-917.

Levine RS, Peterson AT,Benedict MQ 2004. Distribution of members of Anopheles quadrimaculatus Say s. 1. (Diptera: $\mathrm{Cu}-$ licidae) and implications for their roles in malaria transmission in the United States. J Med Entomol 41: 607-613.

Li C, Wilkerson RC 2005. Identification of Anopheles (Nyssorhynchus) albitarsis complex species (Diptera: Culicidae) using rDNA internal transcribed spacer 2-based polymerase chain reaction primers. Mem Inst Oswaldo Cruz 100: 495500 .

Liao D 1999. Concerted evolution: Molecular mechanism and biological implications. Am J Hum Genet 64: 24-30.

Lima JB, Valle D, Peixoto AA 2004a. Adaptation of a South American malaria vector to laboratory colonization suggests faster-male evolution for mating ability. BMC Evol Biol 4: 12.

Lima JB, Valle D, Peixoto AA 2004b. Analysis of reproductive isolation between sibling species Anopheles albitarsis sensu stricto and Anopheles deaneorum, two malaria vectors belonging to the Albitarsis complex (Diptera: Culicidae). JMed Entomol 41: 888-893.
Linthicum KJ 1988. A revision of the Argyritarsis Section of the subgenus Nyssorhynchus of Anopheles (Diptera: Culicidae). Mosq Syst 20: 98-271.

Lounibos LP, Conn JE 2000. Malaria vector heterogeneity in South America. Am Entomologist 46: 238-249.

Lounibos LP, Wilkerson RC, Conn JE, Hribar LJ, Fritz GN, Danoff-Burg JA 1998. Morphological, molecular, and chromosomal discrimination of cryptic Anopheles (Nyssorhynchus) (Diptera: Culicidae) from South America. $J$ Med Entomol 35: 830-838.

Machado RLD, Couto AA R D'Almeida, Cavasini CE, Calvosa VSP 2003. Malaria outside the Brazilian Amazonian region: the situation in Santa Catarina State. Rev Soc Bras Med Trop 36: 581-586.

Malafronte RS, Marrelli MT, Marinotti O 1999. Analysis of ITS2 DNA sequences from Brazilian Anopheles darlingi (Diptera: Culicidae). J Med Entomol 36: 631-634.

Marrelli MT, Branquinho MS, Hoffmann EH, Taipe-Lagos CB, Natal D, Kloetzel JK 1998. Correlation between positive serology for Plasmodium vivax-like/Plasmodium simiovale malaria parasites in the human and anopheline populations in the State of Acre, Brazil. Trans R Soc Trop Med Hyg 92: 149-151.

Marrelli MT, Floeter-Winter LM, Malafronte RS, Tadei WP, Lourenço-de-Oliveira R, Flores-Mendoza C, Marinotti O 2005. Amazonian malaria vector anopheline relationships interpreted from ITS2 rDNA sequences. Med Vet Entomol 19:208-218.

Marrelli MT, Malafronte RS, Flores-Mendoza C, Lourenço-deOliveira R, Kloetzel JK, Marinotti O 1999. Sequence analysis of the second internal transcribed spacer of ribosomal DNA in Anopheles oswaldoi (Diptera: Culicidae). J Med Entomol 36: 679-684.

McMichael C, Waters E, Volmink J 2005. Evidence-based public health: what does it offer developing countries? J Public Health 27: 215-221.

Miller BR, Crabtree MB, Savage HM 1997. Phylogenetic relationships of the Culicomorpha inferred from $18 \mathrm{~S}$ and $5.8 \mathrm{~S}$ ribosomal DNA sequences. (Diptera: Nematocera). Insect Mol Biol 6: 105-114.

Moreno JE, Rubio-Palis Y, Paez E, Perez E, Sanchez V, Vaccari E 2005. Anopheles (Anopheles) neomaculipalpus: a new malaria vector in the Amazon basin? Med Vet Entomol 19: 329-332.

Norris DE 2002. Genetic markers for study of the anopheline vectors of human malaria. Int J Parasitol 32: 1607-1615.

Papavero N, Guimarães JH. 2000. The taxonomy of Brazilian insects vectors of transmissible diseases (1900-2000) - Then and now. Mem Inst Oswaldo Cruz 95: 109-118.

Paskewitz SM, Wesson DM, Collins FH 1993. The internal transcribed spacers of ribosomal DNA in five members of the Anopheles gambiae species complex. Insect Mol Biol 2: 247-257.

Pérez AM, Conn J 1992. A polytene chromosome study of four populations of Anopheles aquasalis from Venezuela. Genome 35: 327-331.

Phillips A, Milligan PJM, Broomfield G, Molyneux DH 1988. Identification of medically important Diptera by analysis of cu- 
ticular hydrocarbons. In MW Service, Biosystematics of Haematophagous Insects, Oxford University Press, New York, p. 61-76.

Porter CH, Collins FH 1991. Species-diagnostic differences in a ribosomal DNA internal transcribed spacer from the sibling species Anopheles freeborni and Anopheles hermsi (Diptera: Culicidae). Am J Trop Med Hyg 45: 271-279.

Póvoa MM, Wirtz RA, Lacerda RNL, Miles MA, Warshurst D 2001. Malaria vectors in the municipality of Serra do Navio, State of Amapá, Amazon Region, Brazil. Mem Inst Oswaldo Cruz 96: 179-184.

Powell JR, Petrarca V, della Torre A, Caccone A, Coluzzi M 1999. Population structure, speciation, and introgression in the Anopheles gambiae complex. Parassitologia 41:101113.

Quiñones ML, Harbach RE, Calle DA, Ruiz F, Erazo HF, Linton Y-M 2001. Variante morfológica de adultos hembras de Anopheles benarrochi (Diptera: Culicidae) en Putumayo, Colombia. Biomedica 21:351-359.

Rachou RG 1958. Anofelinos do Brasil: comportamento das espécies vetoras da malária. Rev Bras Malariol D Trop 10: 145-181.

Ramirez CCL, Dessen EMB 2000a. Chromosomal evidence for sibling species of the malaria vector Anopheles cruzii. Genome 43: 143-151.

Ramirez CCL, Dessen EMB 2000b. Chromosome differentiated populations of Anopheles cruzii: evidence for a third sibling species. Genetica 108: 73-80.

Robert LL, Santos-Ciminera PD, Andre RG, Schultz GW, Lawyer PG, Nigro J, Masuoka P, Wirtz RA, Neely J, Gaines D, Cannon CE, Pettit D, Garvey CW, Goodfriend D, Roberts DR 2005. Plasmodium-infected Anopheles mosquitoes collected in Virginia and Maryland following local transmission of Plasmodium vivax malaria in Loudoun County, Virginia. J Am Mosq Control Assoc 21: 187-193.

Rodriguez MH 2006. Malaria and dengue vector biology and control in Latin America In BGJ Knols, C Louis (eds), Bridging Laboratory and Field Research for Genetic Control of Disease Vectors, Wageningen UR Frontis Series, Springer, Dordrecht, p. 129-144.

Rodriguez MH, Gonzalez-Ceron L, Hernandez JE, Nettel JA, Villarreal C, Kain KC, Wirtz RA 2000. Different prevalence of Plasmodium vivax phenotypes VK210 and VK247 associated with the distribution of Anopheles albimanus and Anopheles pseudopunctipennis in Mexico. Am J Trop Med Hyg 62: 122-127.

Romi R, Boccolini D, Di Luca M, La Rosa G, Marinucci M 2000. Identification of the sibling species of the Anopheles maculipennis complex by heteroduplex analysis. Insect Mol Biol 9: 509-513.

Rosa-Freitas MG, Lourenço-de-Oliveira R, de Carvalho-Pinto CJ, Flores-Mendoza C, Silva-do-Nascimento TF 1998. Anopheline species complexes in Brazil. Current knowledge of those related to malaria transmission. Mem Inst Oswaldo Cruz 93: 651-655.

Rubio-Palis Y, Zimmerman RH 1997. Ecoregional classification of malaria vectors in the Neotropics. J Med Entomol 34: 499-510.

Ruiz F, Quiñones ML, Calle DA, Erazo HF, Alzate JF, Linton
YM 2005. Molecular differentiation of Anopheles (Nyssorhynchus) benarrochi and A. (N.) oswaldoi in Southern Colombia. Mem Inst Oswaldo Cruz 100: 155-160.

Sallum MA, Bergo ES, Flores DC, Forattini OP 2002. Systematic studies on Anopheles galvaoi Causey, Deane \& Deane from the subgenus Nyssorhynchus Blanchard (Diptera: Culicidae). Mem Inst Oswaldo Cruz 97: 1177-1189.

Sallum MAM, Wilkerson RC, Forattini OP 1999. Taxonomic study of species formerly identified as Anopheles mediopunctatus and resurrection of An. costai (Diptera: Culicidae). $J$ Med Entomol 36: 282-300.

Sallum MAM, Schultz TR, Wilkerson RC 2000. Phylogeny of Anophelinae based on morphological characters. Ann Entomol Soc Am 93: 745-775.

Sallum MAM, Bergo ES, Forattini OP 1997. First record of Anopheles benarrochi Gabaldon, Cova Garcia \& Lopez from the State of São Paulo, southern Brazil. Mem Inst Oswaldo Cruz 92: 233-234.

Subbarao SK, Sharma VP 1997. Anopheline species complexes and malaria control. Indian J Med Res 106: 164-173.

Tang J, Toe L, Back C, Unnasch TR 1996. Intra-specific heterogeneity of the rDNA internal transcribed spacer in the Simulium damnosum (Diptera: Simuliidae) complex. Mol Biol Evol 13:244-252.

Tadei WP, Dutary-Thatcher B 2000. Malaria vectors in the Brazilian Amazon: Anopheles of the subgenus Nyssorhynchus. Rev Inst Med Trop São Paulo 42: 87-94.

Tadei WP, Thatcher BD, Santos JM, Scarpassa VM, Rodrigues IB, Rafael MS 1998. Ecologic observations on anopheline vectors of malaria in the Brazilian Amazon. Am J Trop Med Hyg 59: 325-335.

Thompson JD, Higgins DG, Gibson TJ 1994. CLUSTAL W: Improving the sensitivity of progressive multiple sequence alignment through sequence weighting, positions-specific gap penalties and weight matrix. Nucleic Acids Res 22: 4676-4680.

Van Bortel W, Coosemans M 2003. Suggesting new species? Comments on "Evidence for a new species of Anopheles minimus from the Ryukyu Archipelago, Japan”. J Am Mosq Control Assoc 19: 261-264.

Van Bortel W, Harbach RE, Trung HD, Roelants P, Backeljau T, Coosemans M 2001. Confirmation of Anopheles varuna in Vietnam previously misidentified and mistargeted as the malaria vector Anopheles minimus. Am J Trop Med Hyg 65: 729-732.

Wilkerson RC 1991. Anopheles (Anopheles) calderoni n sp., a malaria vector of the Arribalzagia Series from Peru (Diptera: Culicidae). Mosq Syst 23: 25-38.

Wilkerson RC, Parsons TJ, Klein TA, Gaffigan TV, Bergo E, Consolim J 1995. Diagnosis by random amplified polymorphic DNA polymerase chain reaction of four cryptic species related to Anopheles (Nyssorhynchus) albitarsis (Diptera: Culicidae) from Paraguay, Argentina, and Brazil. J Med Entomol 32: 697-704.

Wilkerson RC, Peyton EL 1990. Standardized nomenclature for the costal wing spots of the genus Anopheles and other spotted-wing mosquitoes (Diptera: Culicidae). J Med Entomol 27: $207-224$ 
Wilkerson RC, Reinert JF, Li C 2004. Ribosomal DNA ITS2 sequences differentiate six species in the Anopheles crucians complex (Diptera: Culicidae). J Med Entomol 41: 392-401.

Wilkerson RC, Sallum MAM 1999. Anopheles (Anopheles) forattinii: a new species in series Arribalzagia (Diptera: Culicidae). J Med Entomol 36: 345-354.

Wilkerson RC, Strickman D, Litwak TR 1990. Illustrated key to the female anopheline mosquitoes of Central America and Mexico. J Am Mosq Control Assoc 6: 7-34.
Will KW, Mishler BD, Wheeler QD 2005. The perils of DNA barcoding and the need for integrative taxonomy. Syst Biol 54: 844-851.

Zavortink TJ 1973. Mosquito studies (Diptera: Culicidae) XXIX. A Review of the subgenus Kerteszia of Anopheles. Contrib Amer Entomol Inst 9: 1-54.

Zimmermann RH 1992. Ecology of malaria vectors in the Americas and future direction. Mem Inst Oswaldo Cruz 87: 371383. 